\title{
An Analysis of the Double Victory in Modern Society from the "Old Man and the Sea"
}

\author{
Yuanyuan Zhang \\ School of Foreign Studies, Zhengzhou University of Industrial Technology, Henan 451100, China \\ 270933844@qq.com
}

Keywords: double victory, spiritual victory, material victory, personalities of characters.

\begin{abstract}
Hemingway was one of the most outstanding novelists in America in the twentieth century. His remarkable work, The Old Man and the Sea, is a famous realistic novel. The purpose of this paper is to find factors to success in today's society by analyzing the characters of the old man and the boy, etc. The author insists that the old man certainly succeeds in spirit, the spirit of Never Say Die when facing with setbacks and the adventure in the unknown things, which still has educational significance so far. However, no one can deny that the old man fails in the physical aspects. Real victory must contain both material and spiritual victory. Usually, positive attitude towards life and flexible way of doing things are more beneficial to humanity's survival and development.
\end{abstract}

\section{Introduction}

The Old Man and the Sea holds a special position in Hemingway's works; it is a summary of Hemingway's observation and thinking of life in decades. The book contains rich contents, and still has its enlightening and educational significance today. This paper attempts to study the ingredients of success from both material and spiritual aspects and analyze its realistic significance. One of the most important traits of a successful person is persistence; another is optimistic spirit, aside from unity and understanding himself. Innate quality of the environment cannot decide everything. The key to success lies in entirely his own efforts.

This paper analyzes different people's personalities and then points out two advantages of the old man, which will help modern people have strong spiritual support before doing something. A good state of mind is a prerequisite for success at any time. We should set up a good attitude towards failure and try to deal with them with a calm and cool mind. At the same time, it also emphasizes two points that everybody should pay more attention to them, because they can help us achieve material success easily in modern society. That is ideology of unity and the meaning of recognizing oneself. Unity and mutual assistance are the guarantee of success. When facing with difficulties, the best strategy for moving on is to recognize the reality of the situation and recognize one's ability and find a way to cope with them productively.

Since The Old Man and the Sea was published in 1952, it has become focus of literary circles at home and abroad. This paper summarizes the elements to double success in today's society by analyzing the old man's success in spirit and his failure in material. True success is all-around rather than unilaterally. The study of the novel and the analysis of the protagonists are to help people realize the connotation of double victory, so as to achieve the true success in modern society.

Active optimism and entrepreneurial spirit of Never Give Up can help them make great progress and live happily. Similarly, some people are cheerful, optimistic and doing something pro-active, but they really do not have enough money to spend. That is to say, they are poor in material aspect. Maybe what they lack is ideology and recognizing themselves. We are living in an age where the power of crowds can accomplish big things. Personal power is very limited, while recognizing oneself can save twists and turns and get twofold results with half the effort. Both of them are elements of material success. 


\section{Shaping and Expressing of Personalities of Characters}

\subsection{Introduction to Ernest Hemingway and The Old Man and the Sea}

Ernest Hemingway (1898-1961) is a remarkable writer. He was born on July 21st, 1899 at Oak Park, Illinois, near Chicago in American. He started his career as a writer in a newspaper office in Kansas City at the age of seventeen. At that time Hemingway learned many virtues such as courage and endurance. Hemingway loved to take adventures. After the United States entered the First World War, he joined a volunteer ambulance unit in France. Serving at the front, he was wounded, was decorated by the Italian Government, and spent considerable time in hospitals. After his return to the United States, he became a reporter for Canadian and American newspapers and was soon sent back to Europe to cover such events as the Greek Revolution. During the twenties, he became a member of the group of expatriate in his first important work - The Sun Also Rises. He received the Pulitzer Prize in 1953 for The Old Man and the Sea, and the Nobel Prize in Literature in 1954.

Hemingway's writing style is social. He usually describes his own true experience in his novel. Hemingway creates many "Hemingway heroes". They live in great pressure, they suffer from painful physical wound and terrible mental wound, but they always keep optimistic attitude towards life, such as Santiago in The Old Man and the Sea. Hemingway uses simple and short sentences often connected by "and", "then" and sometimes "so". They are easily understood and can express his feelings correctly. Hemingway uses few adjectives and adverbs in his novels and he never gives over-embellishment and abstract to the sentence. He had the ability to combine simple realism of narrative with complex symbolism of image at once. The implied meaning is left for various explanations and in a sense a far-reaching effect is obtained. The Old Man and the Sea is a story of friendship between a young boy and an aging fisherman tormented by hunger and weeks of ill luck. Santiago, a once strong, proud man, is coming to terms with his failing abilities and age. In some ways, it is Hemingway's style that has a great influence on American life. The work also encourages people never to give up. Life is full of troubles and not easy for everybody, but when people accept all the losses calmly, face the difficulties and shoulder the challenges bravely, people will be surprised to find that nothing cannot be overcome. The most important thing in life is to have a great aim, and the determination to attain it.

\subsection{An analysis of Different People's Personalities}

In The Old Man and the Sea, what impresses people most is the bright contrast of the big image "the old man" and the small image "the little boy". However, we discover that the image of the child is just mentioned at the beginning and in the end of this novel and accounts for a few words; so many researchers ignore the importance of the little boy, while his image and characters actually play important parts in this novel. Besides, the image of the little boy's parents is also necessary in this story. There are few words about other people, but their images still have influence on this novel.

\subsubsection{The Old Man's Personalities}

In appearance, the old man is thin and gaunt; he has deep wrinkles, discolored clothes, but his eyes are perhaps the key to his soul. He has optimistic nature. He is confident enough of catching a very big fish one day. It is hope and strong belief that encourage the old man to insist on going fishing for living. He no longer dreams of storms, fights and women. He only dreams of places now and of the lion on the beach because he regards himself as the savage lion. Though he is old now and his youth or strength is left behind him as time goes by, his dream gives him braveness. Besides, the old man has optimistic attitude towards life no matter what happens. The image of the old man leaves a deep impression on people. While it is such an old man catching no fish in eighty-four days but still insisting on his judgment. He is also a little arrogant, he never forgets how strong he is when he is young. In his own eyes, he is a great man as before. Moreover, the old man dares to take risks. As is known to us, sea is very dangerous because many factors cannot be controlled and predicted by people, but the old man is never afraid of it. Later he encounters a very big Marlin, but also he does not retreat. Afterwards, he fights against schools of sharks without fear. It is his adventurous spirit that makes him great and gives him an unforgettable experience. 
Also, he is too confident that he cannot accept the fact that he is getting old and that he slowly casts his strength. Because of his over-confidence and because he cannot recognize himself clearly, what he brings home is nothing but a bare bone. It is his own reason that makes him fail. What is worse, he does not recognize this point. It seems that he does not care everything and does not mind gain and loss.

\subsubsection{The Little Boy's Personalities}

The little boy, Manolin, is different from those common people. He is quiet and also has his own ideas and thoughts. According to his own will, he does not listen to those who gossip. Meanwhile, he is kind enough and mature. Though the old man is completely a failure in others' eyes: Santiago's life is not in good condition. He lives in an old dirty house in which there is only a bed and one chair. He is so poor that he has no rice and fish to eat. While sailing for fishing, he has only a bottle of water with him. What's more, Santiago has gone out for fishing for 84 days without catching a fish. He has such a bad luck that Manolin is not allowed by his parents to fish with him. In spite of his parents' willing, Manolin keeps caring about the old man. Under these circumstances, Manolin still holds an opinion that Santiago is a great fisherman and he firmly believes that Santiago will make a difference sooner or later. Once Manolin thinks something is right, he will stick with it firmly.

Manolin is not only a little boy, but a mature enough man to look after Santiago and also a loyal friend of Santiago. Though the old man is down and out, and under his parents' pressure, he never quits the old man, but goes to see him and bring him some food from time to time. Success can attract friends; frustration can challenge friends. Although Santiago suffers a series of misfortune, the little boy never leaves him. This point is enough to prove that he is kind and mature. Meanwhile, he is brave. He has a noble spirit, and he is bold and courageous. He is confident of his ability to be able to dry all the undertakings and he considers himself as a valuable person.

\subsubsection{Manolin's Parents' Personalities}

Manolin's parents are short-sighted and anxious to achieve quick success and get instant benefits. They change their view according to the circumstances in the name of love. They only see a poor old man's failure in eighty-four days but neglect the fishing skills and experience of the old man which can help them catch many fish one day. Because of this, they want Manolin to follow a more successful fisherman. It can be seen that compared with abstract mental concept, they tend to pay more attention to real substance. Of course, they love their child, and as parents, all they want is that Manolin can learn some practical skills of fishing and have a bright future.

Meanwhile, they are reasonable. They never force to keep their son away from the old man. Like father like son, it can be seen that they are not as wise as Manolin, but still are decent parents.

\subsubsection{Other People's Personalities}

This novel does not portray too much about other people. It is not difficult to find that they are indifferent to others and mind their own business. The old man lives in bad condition, but no one shows his sympathy to the old man and looks after him except the little boy. Even though they see a big fish bone in the seaside, they do not talk too much about it and regard this experience as a legend. They are materialists. In their opinion, the man who catches more fish is undoubtedly a winner. But Santiago is just an ordinary old man, and he is not a successful man. So no one cares about such an ordinary person; they are busy in their own business in order to catch more fish or make much money.

They are very diligent. They get up to go fishing at dawn every day; it is their habit, and also a part of their life. They are different from the old man; they are content with things as they are and they have no ambitions. They never thought they will catch a big fish that is beyond their imagination one day. They never thought they could be the same person like the old man, and never thought miracle would fall on them. They see themselves as ordinary people. Life simply goes on and they feel happy every day. 


\section{An Analysis of Double Victory}

\subsection{Introduction to Double Victory}

Double victory contains external material victory and the internal spiritual success. Material success refers to enough money to spend, no lack of food, clothes and specific things. Spiritual success refers to health psychology, and good attitude towards life. Success is not simply coming from spiritual support; material aspect also plays an important role. People always pursue the satisfaction of material and spirit. Spiritual fulfillment is the staff of our contemporary life, which can lead people to experience a vibrant and beautiful life. Money can make people choose their life style freely. A decent car, a comfortable house and a decent job can give people a sense of security. Double victory means one not only has money, but also has happiness. The old man is not a real winner, or a real failure either. He only achieves spiritual success.

\subsection{The External Material Success}

The Old Man and the Sea tells a story of a fierce fighting between an old poor fisherman and a large marlin, then most people think highly of the old man's tough man spirit - one can be destroyed, but cannot be defeated. However, few people pay close attention to the old man's failure in material aspect. Though he feels happy and lives freely, he has no food to eat. Food is the substance basis of life. The little boy provides him some material foundation, and then he is still alive and healthy. It is very clear that without food, people cannot live long, and not to mention do some great things and make much money. So material foundation is the premise of doing everything.

No one can deny that the old man is a complete loser in this aspect, especially in modern society. He lives in very poor condition. As the proverb goes, money is not almighty, but having no money makes nothing possible. Each one's basic necessities of life cannot separate from the material; people cannot live without bread, clothes and house. So material and money are needful things for man's existence. A real successful man must have some material basics, after all, material wealth is a sign of success in modern society. There has been a trend in recent years towards the worship of money. A recent survey shows that more and more people rank getting rich as their top priority.

\subsection{The Internal Spiritual Success}

Spiritual success calls for optimism, confidence, serenity, poise, faith, courage, patience, and enthusiasm. Spiritual success is always not arriving at the summit of a mountain as a final destination. It is a burning desire to achieve and is also the courage to meet failure without being defeated. It is a perpetual growth. The old man is surely a successful man in spirit, his positive attitude towards future makes him never feel disappointed but is full of energy all the time.

Though suffering a lot in reality, the old man is still full of confidence to life. The adventurous spirit leads him to make a big difference. His fishing experience is absolutely a tragedy. Though the old man tries his best to struggle with sharks, he gets nothing except a big bare bone eventually. Though he suffers a lot of misfortune, he is still optimistic and keeping good attitude towards tomorrow. In his dreams, he is as strong as the tiger, as happy as nothing had happened.

To live with a high ideal is a successful life. It is not what one does, but what one tries to do makes a man stronger. Though the old man has bad luck for a long time, he still thinks that it is temporary; tomorrow will be better; everything will be OK. He never admits defeat no matter how hard his life is, so he is absolutely a great success in spirit and has encouraged generation after generation in decades.

\section{Entrepreneurial Spirit of Never Give up}

\subsection{Active Optimism}

The first step to success is to develop a good attitude. The old man never knows when and where he can catch a fish, even a small fish. But before good fortune befalls, he keeps the good mindset all the time, and never complains about his bad luck. So that when a big marlin which is bigger and stronger than his imagine suddenly appears, he also can try every means to deal with it calmly. It is a pity that 
Santiago was exhausted and got nothing eventually after several battles between him and sharks. While it is worth mentioning the old man is not extremely disappointed. He returns home and falls asleep soon as nothing had happened. He still dreams pleasant dreams, a big brave tiger just as himself. Though the big Marlin has gone, his dream, his lofty aspirations and his good mentality will lasts forever.

The innermost feelings are stable, not pleased by external gains, not saddened by personal loses, and only then can one keep a cool head and make correct choice. Maintaining good mentality and being patient to everything are not nasty, but a virtue. It is essential condition of those people who want to succeed. In addition, patience will also bring success to people.

\subsection{Ideology of Unity}

The old man's failure in material shows that personal power is extremely limited when against great difficulties, and only by cooperation can he achieve success. Numerous examples can demonstrate the power of unity. In an increasingly harmonious society, it is love and concern that have brought about the great progress. No one can exist in isolation, in that case, why not help each other and pool all efforts together? If the old man goes out for fishing with others, not a lonely one, he would not be so exhausted and such a tragedy would not be staged.

In the same way, a family or a single person in trouble cannot accomplish the task without the help of others. It is the solidarity that will contribute to ultimate success. Individual heroism may often be appreciated by others, while a strong team spirit is much better than it most of the time. One who wants to build a career in modern society have to depend on cooperation.

\subsection{The Meaning of Recognizing Oneself}

Everyone should try to realize his ability, particularly his strengths and weaknesses. Over-confidence leads people to failure. Santiago regards himself as a strong man, maybe once he was, but now he is getting old as time goes by and becoming weak day by day. While he is not aware of this point, he still sees himself as a young man. After a fierce struggle between Santiago and sharks, he feels tired and helpless and gets nothing at last. All his efforts are in vain. The reason why such a tragedy happened is that the old man does not know himself very well. Know yourself as well as the enemy, then you can succeed, or you will fail miserably and expensively.

However, no matter in modern society or at that time, a great number of people were defeated by their own weaknesses. Many people seem very talented person and wonder why they are so great and want to be the same person, while they do not have the patience to figure out who they are and what makes them fail. They take the bull by the horns, fail again and again but never know why, because they never calm down to analyze themselves. A person who knows himself very well will absolutely succeed, because he knows what he should do and what he should not, what he is good at and what he is not good at. Thus, he can do better whatever he does and is not far away from double success.

\section{Summary}

The Old Man and the Sea has more educational significance in double victory aspect. It is an undeniable fact that Santiago's glorious spirit is worth every generation studying and learning. While in modern society, the old man may not be a really successful man according to most people's metric of success. Spiritual victory is the basic of material victory; material victory is the guarantee of spiritual victory; both are indispensable.

This paper discussed the essential elements to double success in today's society by analyzing different people's personalities. The spirit of never-give-up and a positive attitude towards life should be continued to carry forward so that modern people can achieve spiritual victory easily. While to many people, in such a complicated world, the most important thing is to recognize one's advantages and disadvantages very well, to make full use of strong points and avoid weakness and rally together 
to deal with difficulties; only in this way can people achieve material victory. Material victory is extremely important as well as spiritual victory, especially in modern society.

\section{References}

[1]. Hemingway. The Old Man and the Sea, Shanghai: Shanghai Translation Publishing House, 2003, p.36-56.

[2]. Runping Zhang. On the Formation of Hemingway's Fiction Theme. Learning and exploration, Vol.4(2001), p.23-24.

[3]. Wei Zhang. The Narrative Art of Hemingway's Novels. China Social Sciences Press, 2005, p. $55-65$.

[4]. Haiyan Zhou. On the Symbolic Techniques in The Old Man and the Sea. New West, Vol.14 (2010), p.35-37.

[5]. Jizhong Zhu. Multi-layered Meanings - Analysis of the Symbolic Meaning of "The Old Man and the Sea". Journal of Xinjiang Petroleum Education Institute, Vol. 2(2000), p.46-49.

[6]. Zhenwei Zhu. The Aesthetic Creation of Hemingway's Novels. Journal of Shanghai University, Vol.4 (2001), p.5-10. 